DOI: https://doi.org/10.24144/2409-6857.2020.2(56).22-28

УДК 61.331.105

Криничко Л.Р., Криничко Ф.Р., Петрик С.М.

\title{
АЛГОРИТМ РЕАЛІЗАЦІЇ ДЕРЖАВНО-ПРИВАТНОГО ПАРТНЕРСТВА В СФЕРІ ОХОРОНИ ЗДОРОВ'я
}

\begin{abstract}
Стаття присвячена розробленню алгоритму формування та реалізації проектів державноприватного партнерства в сфері охорони здоров'я Украӥни. Досліджено впроваджені проекти, які позиціонуються як приклади державно-приватного партнерства у сфері охорони здоров'я в Україні та проекти державно-приватного партнерства, які перебувають на етапі впровадження. Визначено етапи формування те реалізаџіі проектів державно-приватного партнерства в сфері охорони здоров'я. Обгрунтовано, що найпоширенішими формами реалізаиії проектів державно-приватного партнерства в Україні є спільна діяльність, концесія та оренда. Проаналізовано кількість проектів державно-приватного партнерства за галузями в розрізі регіонів України. Досліджено властивості та відмінності форм реалізації проектів державноприватного партнерства. Охарактеризовано місие держави в реалізації різних форм проектів державно-приватного партнерства. Зроблено висновок, що держава як партнер в проекті державно-приватного партнерства в срері охорони здоров'я приймає різну участь, від повноцінного суб'єкта управління до орендодавця. Сформульовано напрями, в яких доцільно трансформувати систему державного управління в галузі охорони здоров'я.
\end{abstract}

Ключові слова: охорони здоров'я, державно-приватне партнерство, проект, договір про спільну діяльність, концесія, оренда.

Постановка проблеми. Тенденції розвитку суспільних відносин, ставлять державне управління перед потребою трансформації механізмів та розробки нових напрямів державної політики в сфері охорони здоров'я. Особливо гостро дане питання стоїть в умовах нових викликів, що стоять перед людством, а саме глобальні пандемії та епідемії хвороби. Зазначені виклики $є$ загрозою здоров'я нації, а тому потребують інноваційних рішень щодо розвитку системи охорони здоров'я. Таким рішенням сьогодні $€$ державно-приватне партнерство. «За останнє десятиліття фінансування в рамках державно-приватного

(c) Криничко Л.Р., к.мед.н, здобувач, Державний університет «Житомирська політехніка», м. Житомир, тел.: (0412) 24-14-22, E-mail: krynychkoliliia@gmail.com

Криничко Ф.P., здобувач кафедри економічної безпеки, публічного управління та адміністрування, Державний університет «Житомирська полі-техніка», м. Житомир, тел.: (0412) 24-14-22, E-mail: felikskrinicko@gmail.com

Петрик С.М., аспірант кафедри публічного адміністрування, Міжрегіональна академія управління персоналом, м. Київ, E-mail: petryk_sergii1@ukr.net партнерства стає все більш популярним у всьому світі, як спосіб підтримки i фінансування громадських і квазігромадських благ в таких секторах, як транспорт (автомобільні і залізні дороги, мости, тунелі, порти, аеропорти), соціальна інфраструктура (лікарні, школи, соціальне житло), комунальні послуги (водопос-тачання, очищення стічних вод, утилізації відходів) і державні установи» [1].

Аналіз останніх досліджень і публікацій. Питання трансформації зміни ролі держави в контексті реалізації проектів державноприватного партнера піднімалися в працях вітчизняних та зарубіжних вчених, зокрема: Н.Г. Александрова, І. Ананов, А. Аскеров, С. В. Бабаєва, М. Й. Байтіна, П. Василенков, С. Голунський, Г. Сллінек, Л. Дюги, А.І. Денисова, О. О. Джураєвої, Л.І. Загайнова, П. Кельзен, А.П. Косіцина, В. Копсйчиков, А.В. Меліхової, Г. Петров, В. Сирих М. Строгович, А. Сміт, К. Шмітт, Ф. Фукуяма та інші. Віддаючи належне вказаним вченим варто наголосити, що в умовах зміни внутрішнього та зовнішнього середовища функціонування держави відбувається в трансформації іiі функцій за змістом та формою. В свою чергу державно-приватне партнерство в сфері охорони здоров'я змінює як зміст функцій так і форму їх реалізації. 
Формулювання цілей статті. Мета даної публікації полягає у розробленні алгоритму формування та реалізації проектів державноприватного партнерства в сфері охорони здоров'я України.

Опис основного матеріалу дослідження. «Проекти, які позиціонуються як приклади державно-приватного партнерства у сфері охорони здоров'я в Україні, однак не $\epsilon$ такими за своєю природою і були реалізовані поза вимогами Закону «Про державноприватне партнерство»:

- Український центр томотерапії на базі Кіровоградського обласного онкологічного диспансеру (внесок публічного партнера 22 площа центру 1000 кв. м., внесок приватного партнера - високоспеціалізоване обладнання, в т.ч. лінійний прискорювач, та безкоштовне лікування 50 пацієнтів на рік);

- Сумський обласний центр служби крові (створення спільного підприємства на 25\% участь ОМС та $75 \%$ участі приватного інвестора ТОВ «Біофарма»; вигода приватного інвестора полягає в отриманні доступу до придбання компонентів крові, які ТОВ «Біофарма» використовує за своєю основною діяльністю для виготовлення препаратів крові);

- Клінічний науково-методичний центр рентгенендоваскулярної медицини на базі університетської клініки Одеського національного медичного університету (внесок приватного партнера високоспеціалізоване обладнання, в т.ч. ангіограф);

- Центр медичних інновацій Novo на базі Львівської комунальної міської дитячої клінічної лікарні (внесок приватного партнера - ремонт приміщення та високоспеціалізоване обладнання);

Проекти, які позиціонуються як приклади державно-приватного партнерства у сфері охорони здоров'я в Україні, що перебувають на етапі впровадження (у т.ч. 3 врахуванням вимог Закону «Про державно-приватне партнерство»):

- Будівництво та відкриття Діагностичного центру на території Бориспільської центральної районної лікарні (добудова площею 300 кв.м. до головного корпусу). Приватний партнер: ТОВ «СканДіагностика» (проект реалізовано як приватну ініціативу);

- готується до оголошення конкурсу проект щодо створення Центру малоінвазивної хірургії на базі третього поверху хірургічного корпусу Трускавецької міської лікарні (на умовах спільної діяльності);

- на етапі розробки ТЕО знаходиться проект IFC щодо об'єднання кількох старих лікарень в одну нову (КМДА спільно з IFC)» [2].

На основі вивчення наукової літератури та практики реалізації проектів державноприватного партнерства, нами визначені наступні етапи формування та реалізації таких проектів в сфері охорони здоров'я:

- прийняття рішення про проект державноприватного партнерства в сфері охорони здоров'я;

- вибір форми реалізації державноприватного партнерства;

- вибір приватного партнера;

- договірний процес;

- формування ресурсів для реалізації проекту державно-приватного партнерства;

- реалізація проекту державно-приватного партнерства в сфері охорони здоров'я;

- контроль за виконанням проекту з боку держави як регулятора та як державного партнера;

- припинення реалізації проекту державноприватного партнерства в сфері охорони здоров'я;

- приймання-передача результатів реалізації проекту державно-приватного партнерства.

Аналізуючи вище представленні етапи можна сформувати наступний алгоритм формування та реалізації проектів державноприватного партнерства в сфері охорони здоров'я (рис. 1).

Найбільш поширенішими формами реалізації проектів державно-приватного партнерства в Україні є: спільна діяльність, концесія, оренда. Так, за даними Міністерства розвитку економіки, торгівлі та сільського господарства в Україні «в Україні станом на 01.01.2020 на засадах ДПП укладено 187 договорів, 3 яких реалізується 52 договори (34 - договорів концесії, 16 - договорів про спільну діяльність, 2 - інші договори), 135 договори не реалізується (4 договори закінчено термін дії, 18 договорів - розірвано, 113 договорів - не виконується)» [3].

На рисунку 2 відображено регіональний розподіл кількості договорів про державноприватне партнерство за різними галузями національної економіки в тому числі в сфері охорони здоров'я 


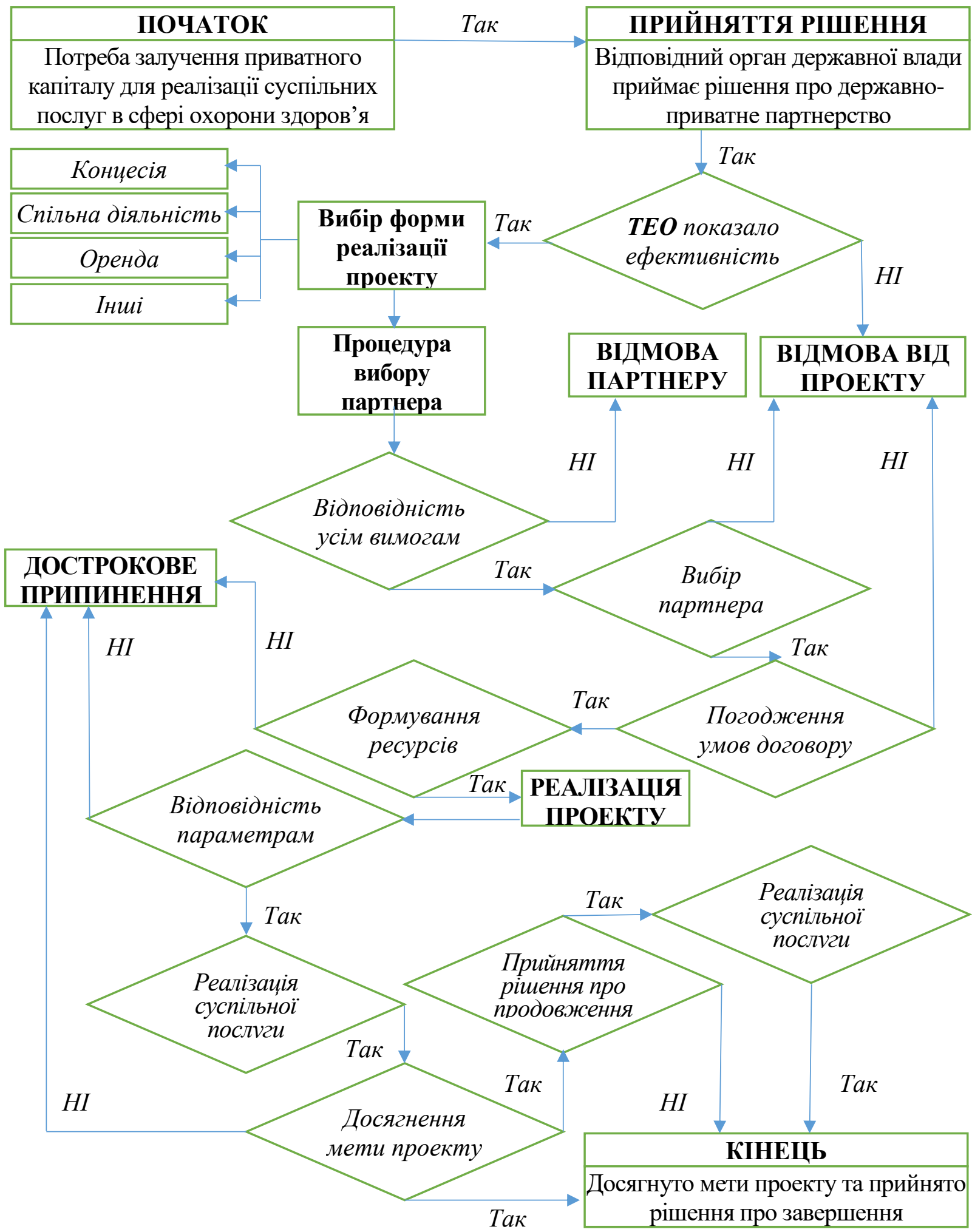

Рис. 1. Алгоритм формування та реалізації проектів державно-приватного партнерства в сфері охорони здоров'я 


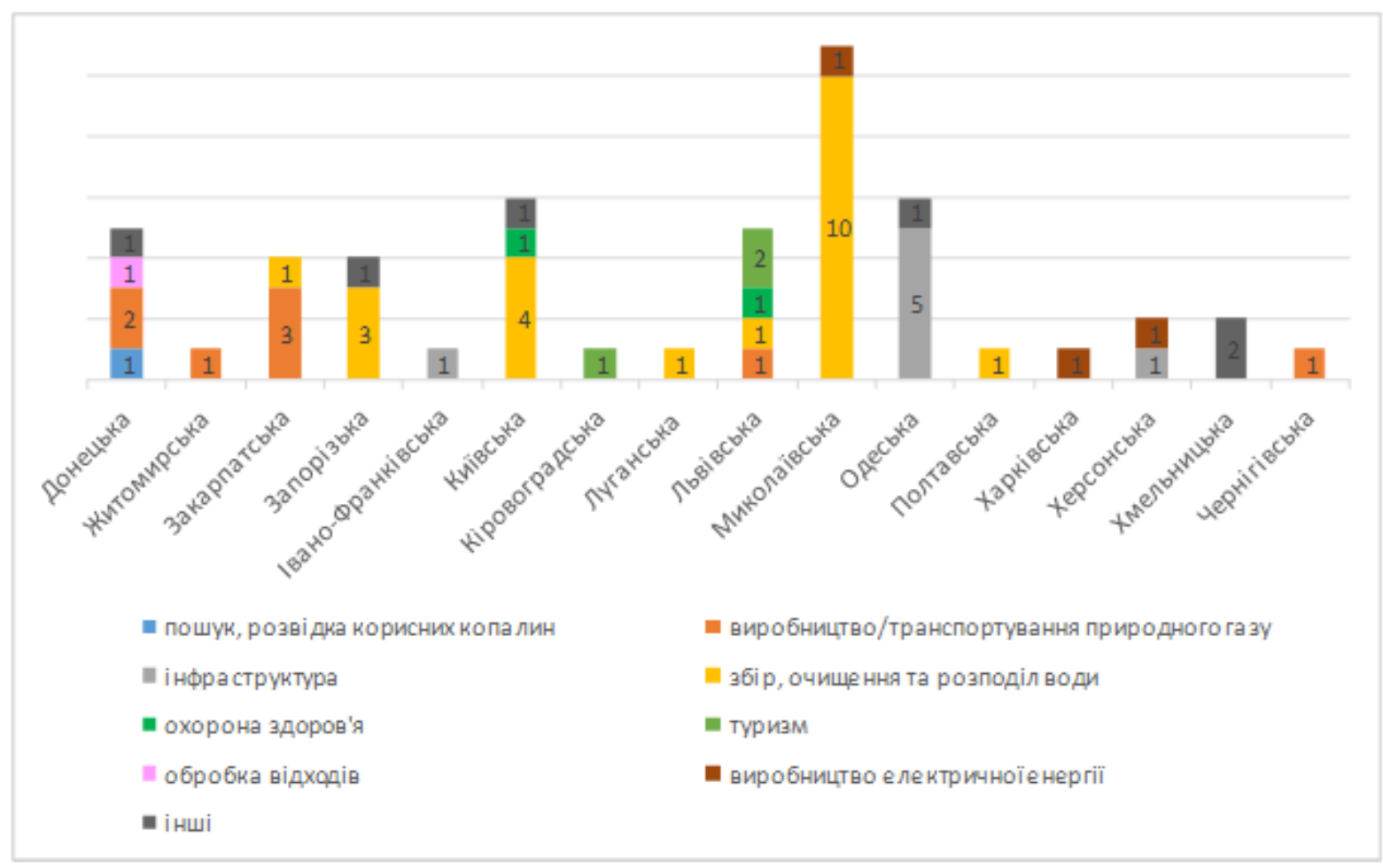
Рис. 2. Кількість проектів державно-приватного партнерства за галузями в розрізі
регіонів[4]

Щодо властивостей форм реалізації проектів державно-приватного партнерства досить цікаву позицію висловив M.I. Тітарчук, який вказав на відмінності різних форм, зокрема:

«-концесія та спільна діяльність. Відмінності між концесією та спільною діяльністю полягають в тому, що метою першої $\epsilon$ задоволення відповідних громадських потреб через модернізацію та управління певним об'єктом майна, що знаходить в державній або комунальній власності, при чому економічна вигода держави зазвичай $\epsilon$ встановленою в концесійному договорі - концесійний платіж («плата, яку обумовлена в концесійному договорі, яку вносить концесіонер за право створення (будівництва) та (або) управління (експлуатації) об'єктів, що надаються в концесію»). В свою чергу характерною рисою спільної діяльності є отримання відповідних економічних вигід органом державної влади чи комунальної організації від здійснення господарської діяльності без створення юридичної особи, тобто націлена на реалізацію довгострокових та короткострокових комерційних проектів. В свою чергу спільна діяльність є об'єктом спільного управління та контролю. При концесії досягається суспільний інтерес через модернізацію інфраструктури і відповідно підвищення якості громадських послуг, а при спільній діяльності суспільний інтерес може не переслідуватися, тобто в більшій мірі реалізація такого проекту націлена на отримання економічних вигід 3 обох сторін. При концесії основна вимога - це модернізація певного об'єкту державної чи комунальної власності, використання якого забезпечує надання суспільних послуг, а при спільній діяльності модернізація може не відбуватися, але використовуються лише спільні ресурси як приватного так i державного партнера. Результатом для держави при концесії $\epsilon$ як суспільний суспільний інтерес, так і концесійний платіж, що встановлюється в договорі. При спільній діяльності встановленої економічної вигоди не прослідковується, відповідно держава може отримати як прибутки, так і збитки, якщо проект не реалізувався або став не ефективним. Крім того, при спільній діяльності як державний, так і приватний партнери повинні інвестувати в спільну діяльність для реалізації основної мети державно-приватного партнерства. Іншою 
відмінністю є організація процесу управління таким проектом державно-приватного партнерства. Так, при спільній діяльності обирається суб'єкт-оператор спільної діяльності, який й здійснює управління реалізацією проекту державно-приватного партнерства. Таким суб'єктом може бути як приватний партнер, так i орган державної влади чи державне або комунальне підприємство.

- концесія та оренда. Основними відмінностями зазначених форм реалізації державно-приватного партнерства $є$ наступні: 1) об'єкт оренди, що знаходить в державній або комунальній формі власності не носить суттєвого суспільного значення, а отже не використовується або неефективно використовується органами державної влади, державними або комунальними підприємства;
2) економічна вигода для держави може визначатися лише орендною платою та зменшенням витрат на утримання та експлуатацію такого об'єкту державного майна; 3) приватний партнер не зобов'язаний виконувати будь-які роботи 3 модернізації об'єкту державного майна, а його експлуатація та управління лише в окремих випадках обмежується договором оренди; 4) строк дії такої форми реалізації державно-приватного партнерства регулюється договором оренди» [5].

В цілому роль держави та органів державного управління за кожним етапом відрізняється як за змістом так i безпосередньою участю в реалізації проекту державно-приватного партнерства. Характеристика місця держави в реалізації різних форм проектів представлено в табл. 1.

\section{Таблиця 1}

Участь держави в реалізації державно-приватного партнерства

\begin{tabular}{|c|c|c|c|}
\hline \multirow{2}{*}{$\begin{array}{l}\text { Напрями участі в } \\
\text { реалізації проекту }\end{array}$} & \multicolumn{3}{|c|}{ Форми реалізації проектів державно-приватного партнерства } \\
\hline & Концесія & Спільна діяльність & Оренда \\
\hline $\begin{array}{c}\text { Загальна } \\
\text { характеристика }\end{array}$ & $\begin{array}{lr}\text { Держава передає об’єкти } \\
\text { державного } \\
\text { комунального та } \\
\begin{array}{l}\text { концесіонеру дайна } \\
\text { лізації послуг в }\end{array} \text { сеа- } \\
\text { охорони здоров'я } \\
\end{array}$ & 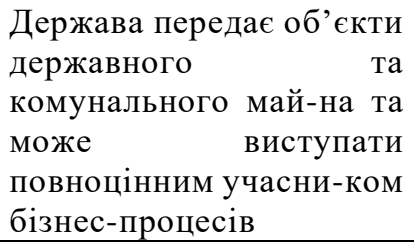 & 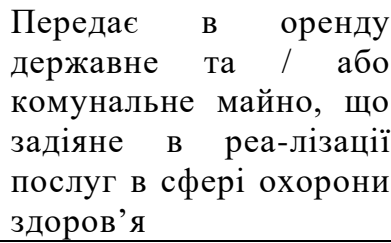 \\
\hline $\begin{array}{c}\text { Постачальник } \\
\text { ресурсу }\end{array}$ & $\begin{array}{l}\text { Цілісні } \\
\text { комплекси, що задіяні в } \\
\text { реалізації послуг в сфері } \\
\text { охорони здо-ров'я, що в } \\
\text { результаті } \\
\text { модернізований }\end{array}$ & $\begin{array}{lr}\text { Залежить від } & \text { мети } \\
\text { проекту, } & \text { може } \\
\text { передбачати } & \text { спільне } \\
\text { використання } & \text { дер- } \\
\text { жавного а } & \text { кому- } \\
\text { нального майна } & \\
\end{array}$ & 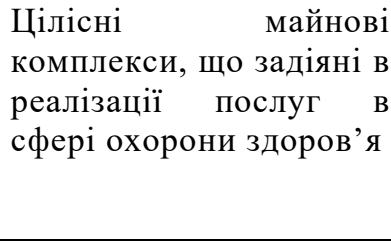 \\
\hline Трудова участь & Не приймає участі & $\begin{array}{l}\text { Можлива, залежить від } \\
\text { умов договору }\end{array}$ & Не приймає участі \\
\hline $\begin{array}{c}\text { Участь в } \\
\text { управлінні }\end{array}$ & Не приймає участі & $\begin{array}{lr}\text { Залежить від } & \text { обра-ного } \\
\text { оператора } & \text { спіль-ної } \\
\text { діяльності. } & \text { Якщо } \\
\text { державний } & \text { партнер } \epsilon \\
\text { оператором } & \text { то вся } \\
\text { система } & \text { управління } \\
\text { залежна від нього }\end{array}$ & Не приймає участі \\
\hline Розрахунки & $\begin{array}{l}\text { Концесійні платежі, які } \\
\text { розраховують відповідно } \\
\text { до затвердженої методики }\end{array}$ & $\begin{array}{l}\text { Розподіл прибутку від } \\
\text { реалізації } \\
\text { інноваційного продукту }\end{array}$ & $\begin{array}{l}\text { Орендні платежі за } \\
\text { користування дер- } \\
\text { жавним та / або } \\
\text { комунальним майном }\end{array}$ \\
\hline Контроль & $\begin{array}{l}\text { В частинні використання } \\
\text { майна, його модернізації } \\
\text { та якості реалізований } \\
\text { послуг в сфері охорони } \\
\text { здоров'я }\end{array}$ & $\begin{array}{lr}\text { Якщо } & \text { державний } \\
\text { партнер є оператором усі } \\
\text { функції } \\
\text { контролю } \\
\text { представнного } \\
\text { преле-жать }\end{array}$ & $\begin{array}{l}\text { В частинні } \\
\text { використання майна }\end{array}$ \\
\hline Результати & $\begin{array}{lr}\text { Модернізований об’єкт та } \\
\text { налагоджена } \\
\text { реалізації } \\
\begin{array}{l}\text { послуг } \\
\text { суспема }\end{array} \\
\end{array}$ & $\begin{array}{l}\text { Інноваційний продукту в } \\
\text { сфері охорони здоров’я }\end{array}$ & $\begin{array}{l}\text { Налагоджена система } \\
\text { реалізації суспільних } \\
\text { послуг }\end{array}$ \\
\hline
\end{tabular}


Таким чином, представлений підхід вказує, що держава як партнер в проекті державноприватного партнерства в сфері охорони здоров'я приймає різну участь, від повноцінного суб'єкта управління до орендодавця. Відповідно система державного управління має трансформувати в наступних напрямам:

1. Розробка та реалізації державної політики в сфері реформування систем охорони здоров'я, в частинні пом'якшення вимог до залучення приватного капіталу, формування державної підтримки приватного сектору;

2. Удосконалення системи нормативноправового регулювання державно-приватного патерства в сфері охорони здоров'я через встановлення чітких вимог до конкурсу та претендентів, порядок трудової участі та участі в управлінні проектом відповідального органу державної влади, порядок здійснення контролю за реалізацією проекту, порядок припинення реалізації проекту державноприватного партнерства;

3. Удосконалення механізму реалізації суспільних послуг в сфері охорони здоров'я через державно-приватні партнерства, що має передбачати формування наступних нормативних положень:

3.1. положення про інвентаризацію об'єктів необоротних активів в сфері охорони здоров'я на та іï основі формування переліку стратегічних об'єктів, що можуть бути передані в державно-приватне партнерство;

3.2. положення про пріоритетні напрями державно-приватного партнерства в сфері охорони здоров'я.

Висновки i перспективи подальших досліджень $\mathbf{y}$ даному напрямку. Запропоновано алгоритм формування та реалізації проектів державно-приватного партнерства в сфері охорони здоров'я, що передбачає наступні етапи: 1) прийняття рішення про проект державно-приватного партнерства в сфері охорони здоров'я; 2) техніко-економічна оцінка проекту державноприватного партнерства; 3) вибір форми реалізації державно-приватного партнерства; 4) вибір приватного партнера; 5) договірний процес;

6) формування ресурсів для реалізації проекту державноприватного партнерства; 7) реалізація проекту державно-приватного партнерства в сфері охорони здоров'я; 8) контроль за виконанням проекту з боку держави як регулятора та як державного партнера; 9) припинення реалізації проекту державно-приватного партнерства в сфері охорони здоров'я; 10)приймання та передача результатів реалізації проекту державно-приватного партнерства. Встановлено механізм участі держави в реалізації таких проектів за складовими: постачальник ресурсів, трудова участь, участь в управлінні, розрахунки, контроль, результати.

\section{ПЕРЕЛІК ВИКОРИСТАНИХ ДЖЕРЕЛ}

1. Закон України «Про державно-приватне партнерство» №2404-VI від 25.10.2020 р. Електронний ресурс. - Режим доступу: http://zakon2.rada.gov.ua/laws/show/2404-17

2. Аржаник Е.П. Финансовое моделирование проектов государственно-частного партнерства. дис. по специальности 08.00.10 - Финансы, денежное обращение и кредит, 2014, С.Петербург, Електронний pecypc. - Режим доступу: https://disser.spbu.ru/disser2/disser/Arzhanik_diss.pdf

3. Методичні рекомендації для впровадження проектів державно-приватного партнерства у сфері охорони здоров'я. МОЗУ. 2018. 72 с. - Електронний ресурс. - Режим доступу: https://moz.gov.ua/uploads/1/7840-1234567890.pdf

4. Стан здійснення ДПП в Україні. 2020. - Електронний ресурс. - Режим доступу: https://www.me.gov.ua/Documents/Detail?lang=uk-UA\&id=9fc90c5e-2f7b-44b2-8bf1-

1ffb7ee1be26\&title=StanZdiisnenniaDppVUkraini

5. Тітарчук M.I. Концесія як форма реалізації державно-приватного партнерства як об'єкту економічного аналізу // Економічний простір. - 2018. - № 139. - С. 199-212.

\section{REFERENCES}

1. Zakon Ukrajiny «Pro derzhavno-pryvatne partnerstvo» [Law of Ukraine "On Public-Private Partnership"] (2020). Vol. 2404-VI Elektronnyj resurs. - Rezhym dostupu: http://zakon2.rada.gov.ua/laws/show/2404-17

2. Arzhanyk E.P. (2014). Fynansovoe modelyrovanye proektov ghosudarstvenno-chastnogho partnerstva [Financial modeling of public-private partnership projects]. dys. po specyaljnosty 08.00.10 - Fynansы, denezhnoe obrashhenye y kredyt, 2014, S.Peterburgh, Elektronnyj resurs. - Rezhym dostupu: https://disser.spbu.ru/disser2/disser/Arzhanik_diss.pdf 
3. Metodychni rekomendaciji dlja vprovadzhennja proektiv derzhavno-pryvatnogho partnerstva u sferi okhorony zdorov'ja [Methodical recommendations for the implementation of public-private partnership projects in the field of health care]. MOZU. 2018. Elektronnyj resurs. - Rezhym dostupu: https://moz.gov.ua/uploads/1/78401234567890.pdf

4. Stan zdijsnennja DPP v Ukrajini [The state of PPP implementation in Ukraine]. 2020. - Elektronnyj resurs. Rezhym dostupu: https://www.me.gov.ua/Documents/Detail?lang=uk-UA\&id=9fc90c5e-2f7b-44b2-8bf11ffb7ee1be26\&title=StanZdiisnenniaDppVUkraini

5. Titarchuk, M.I. (2018). Koncesija jak forma realizaciji derzhavno-pryvatnogho partnerstva jak ob'jektu ekonomichnogho analizu [Concession as a form of public-private partnership as an object of economic analysis] // Ekonomichnyj prostir. Vol.139. - S. 199-212.

Отримано 08.12.2020 